\title{
HISTOPATHOLOGY OF ANTICARSIA GEMMATALIS HÜBNER (LEPIDOPTERA; NOCTUIDAE) TREATED WITH NUCLEOPOLYHEDROVIRUS AND BACILLUS THURINGIENSIS SEROVAR KURSTAKI
}

\author{
Neiva Knaak*; Lidia Mariana Fiuza* \\ Laboratório de Microbiologia, Universidade do Vale do Rio dos Sinos, São Leopoldo, RS, Brasil \\ Submitted: December 17, 2002; Returned to authors for corrections: June 03, 2004; Approved: May 27, 2005
}

\begin{abstract}
The Anticarsia gemmatalis is responsible for the use of chemical insecticides in the soybean culture, causing a significant increase in the costs of farming and a great unbalance in the ecosystem. The use of microbial agents, like Bacillus thuringiensis serovar kurstaki (Btk) and Anticarsia gemmatalis nucleopolyhedrovirus $(A g N P V)$, they are an alternative to chemical control of the pest insects. In the interaction analysis of the entomopathogenic bacteria and virus it is considered important the in vitro action mode of these microbiology control agents. Therefore, the present study aims the histopathological analysis of the A. gemmatalis larvae digestive system after the interaction in vivo of the entomopathogenic $B t k$ and $A g N P V$, represented the Dipel and Baculovirus anticarsia formulations, respectively. The evaluations were realized in larvae of 2nd instar, in which the mortality was evaluated daily, and a histopathology was done with collected larvae in time of 1 , 3, 6, 12 and 24 hours after the treatments application. The results of the in vivo assays reveal that the treatment using the association of $A g N P V-B t k$ (98.68\% of mortality) was more efficient than using $A g N P V$ isolatedly (81.28\% of mortality), but the Btk when used isolatedly had a mortality of $100 \%$. The treatments showed significant $(\mathrm{P}<0.05)$ differences between $A g \mathrm{NPV}$ and $B t k, A g \mathrm{NPV}$ and $A g \mathrm{NPV} / B t k$. The histopathological analysis of the $A g \mathrm{NPV}$ and $B t k$ in A. gemmatalis larvae suggests that the Dipel and Baculovirus anticarsia products were more efficient when they were used simultaneously, because the action of $A g N P V$ was intensified when used in association with Btk, causing changes in the larvae midgut after 6 hours of treatments. When the entomopathogens were used isolating the gut cells alterations were observed only 12 hours after the treatments.
\end{abstract}

Key words: virus, bacteria, biological control, Lepidoptera

\section{INTRODUCTION}

The velvetbean caterpillar Anticarsia gemmatalis Hübner (Lepidoptera: Noctuidae) is an important insect pest of the soybean fields in Brazil. The larva cause serious damage by reducing the leaf area greatly and, consequently, reducing photosynthesis and productivity (18).

Among the alternatives to control this pest, the use of Bacillus thuringiensis has gained attention due to its efficiency and low impact on natural enemies (3). B. thuringiensis is a Gram-positive, aerobic or facultative anaerobic entomopathogenic bacterium found in soil, on plant surfaces, and in grain storage dust. During sporulation $B$. thuringiensis produce crystalline protein inclusions (i.e. crystal). When ingested by insects, this crystal is dissolved in the midgut, discharging proteins denominated deltaendotoxins or Cry proteins. Those proteins after hydrolysis have specific toxin activity for insects and other invertebrate, not causing harmful effects in other organism (25). In the midgut, the proteases activate these proteins that interact with the epithelial membrane, causing the insect death (6). In the field, as in the

*Corresponding Author. Mailing address: Laboratório de Microbiologia, Universidade do Vale do Rio dos Sinos, Av. Unisinos, 950. 93001-970, São Leopoldo, RS, Brasil. Fax: (+5551) 591-1100, E-mail: neivaknaak@gmail.com; fiuza@unisinos.br 
soybean farming's that agent of biological insects control is used in formulations as the Dipel product (Abbott Laboratories of Brasil Ltda).

In the microbial control context, the Anticarsia gemmatalis nucleopolyhedrovirus $(A g N P V)$ stands out as the most important virus used in the insects biological control (5). In natural conditions, the curse is infected commonly when ingesting the contaminated food. After the ingestion, the bodies of polyhedral inclusion, finding alkaline conditions in the mesenterum are dissolved, liberating the virions. The virus begins multiplying itself in the nucleus cells of the insect, dispersing itself for the whole insect body, provoking death, usually from 6 to 8 days after the ingestion $(12,24)$.

To understand the mode action of entomopathogenic bacteria and virus, it is important to knowledge of the insect histopatology. The insect digestive system's is one main physiochemical barriers against the pathogenic agents. In this way, the morphology and physiochemical aspects can support to understand of the insect defense mechanism's (16).

Like this, the present study aimed the histopathological analysis of the A. gemmatalis larvae digestive system, after the interaction in vivo of the entomopathogenic Bacillus thuringiensis kurstaki and Anticarsia gemmatalis nucleopolyhedrovirus, representing the formulations Dipel (Abbott) and Baculovirus anticarsia (Embrapa-CNPSo), respectively.

\section{MATERIALS AND METHODS}

\section{Insects}

The Anticarsia gemmatalis were obtained from soybean fields in the Rio Grande do Sul state and maintained in laboratory in the Ciências da Saúde of the Universidade do Vale do Rio dos Sinos (UNISINOS). The insects were maintained in the laboratory at $70 \%$ relative humidity, photoperiod of 12 hours and $25^{\circ} \mathrm{C}$. Larvae were reared with artificial diet prepared according to Greene et al. (14).

\section{Bioassay}

The bioassays were accomplished in the same laboratory and on controlled conditions $\left(25^{\circ} \mathrm{C}, 70 \%\right.$ of Relative humidity and 12 hours of photoperiod), using larvae of 2nd instar of $A$. gemmatalis, conditioned in acrylic mini-plates $(35 \mathrm{~mm}$ of diameter), in which was previously applied Greene's diet (14). In assays were used in the treatments Anticarsia gemmatalis nucleopolyhedrovirus (AgNPV) and Bacillus thuringiensis serovar kurstaki (Btk), strain HD1. The products were obtained from A. gemmatalis Baculovirus (EMBRAPA/CNPSo) and Dipel (Abbott Laboratories of Brazil Ltda.), respectively. Were applied in the artificial diet the treatments Btk; $A g N P V ; B t k+A g N P V$ and witness ( $100 \mu \mathrm{L}$ of $\mathrm{NaCl} 0.85 \%$ solution). Considering the treatments, to reach the wanted concentration $\left(3.10^{7}\right.$ particles/
$\mathrm{mL}$; for $A g N P V$ and $2.5 .10^{7}$ cells $/ \mathrm{mL}$; for $B t k$ ) dilutions were made and the exact number of bacterial cells and viral polyhedrons were determined in Neubauer chamber. After the treatments application, 20 insects were individually conditioned, in which four repetitions were accomplished by treatment. The mortality was daily evaluated until the 7 th day after the treatments application and the corrected mortality was calculated according to Abbott (1). Data were subjected either to one-way analysis of variance (ANOVA), TUKEY 5\% and factorial analysis of variance (FANOVA) depending upon the experimental design.

\section{Insects' tissues}

The A. gemmatalis larva were prepared according to the inclusion paraffin techniques. During the bioassay, 20 larvae were used for each treatment and 20 to witness, in which they were collected in periods of 1, 3, 6, 12 and 24 hours, after the treatments application. After the fixation, in Bouin Hollande Sublime (BHS) for 24 hours (7), the tissues were submitted to dehydration in ethanol solutions in growing order of graduation (70, 96 and 100\%), following by fast baths of xylol and impregnation in paraffin. The longitudinal histological cuts were accomplished to $5 \mu \mathrm{m}$ thickness, in the histology laboratory (UNISINOS). To remove the paraffin, the slide containing the tissue passed by xylol and ethanol baths in decreasing order of graduation. The staining, of the tissues of A. gemmatalis was made with Heidenhain's Blue. The glasses were mounted with Etellan. The longitudinal sections of the gut tissues of the $A$. gemmatalis larvae were observed under direct optical microscopy were amplified 400 times.

\section{RESULTS AND DISCUSSION}

\section{Pathogenicity in vivo}

The evaluations of the pathogenicity were considering the Anticarsia gemmatalis corrected mortality medium, in which the treatment with Anticarsia gemmatalis nucleopolyhedrovirus $(A g N P V)$ was verified a mortality of $81.28 \%$, in the association $B t k / A g N P V$, the mortality was 98.68\% and only Bacillus thuringiensis serovar kurstaki (Btk) was equivalent to $100 \%$. The results, in vivo, reveal that regarding association treatment $A g N P V / B t k$ was more efficient than only $A g \mathrm{NPV}$, however only Btk caused a similar mortality. The in vivo toxicity obtained in this study using $2.5 .10^{7}$ cells/ $\mathrm{mL}$ of the Btk HD1 against the target species was similar to those obtained by Bobrowski et al. (8 and 9) using Btk HD73 and Btk UNI872 strains.

Considering the lethal time, through the daily analysis of the bioassay, it was observed that the treatment with Btk on the 3rd day after the treatment (DAT) caused $96.05 \%$ of mortality, keeping like this until 7th DAT. As for the treatment with $A g N P V$, in 3rd DAT there was a mortality of $25 \%$ that raised itself to 
$61.05 \%$ in 7 th DAT. In the association $B t k / A g N P V$, the mortality was of $45 \%$ in 2nd DAT, with a peak of $85 \%$ in 3rd DAT, causing $90.26 \%$ of mortality in 7 th DAT (Fig. 1). The treatments showed significant ( $\mathrm{P}<0.05)$ differences in $A g \mathrm{NPV}$ and Btk, AgNPV and AgNPV/Btk.

These results can indicate that the natural resistance factor is very important at the moment of applying the biopesticide against A. gemmatalis larvae. Showing that the control's integrate method, using Btk HD1 (Dipel) and $A g$ NPV (Baculovirus), is a good alternative to reduce the problems concerning the resistance to the population of target pest. Janmaat et al. (15) mentioned that the continued use of the $B t$ microbial pesticide was directly correlated with the concentration's increase of Bt applied by treatment. According to Abot et al. (2), A. gemmatalis has a high potential of developing resistance to the Anticarsia gemmatalis AgNPV in Brazil, where the virus occurs naturally and is extensively employed as a microbial pesticide in the soybean fields. In the United States, the potential for resistance interfering with a microbial insecticide based on $A g N P V$ is lower. Resistant insects also had longer life spans, a lower rate of larval survival in rearing and lower pupa weights than susceptible insects (13).

\section{Histopathology in vitro}

The observations in optical microscopy analysis, of the midgut of $A$. gemmatalis larvae, when compared with the witness (Fig. 2A), show changes in the structure of the midgut, after 24 hours of the treatment with Btk (Fig. 2C), where was

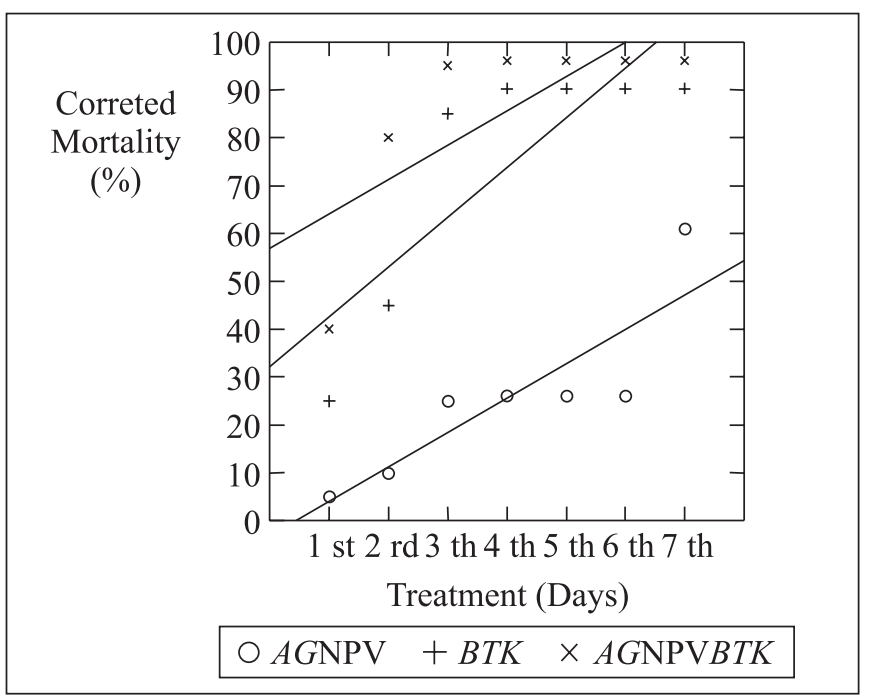

Figure 1. Lethal time of Anticarsia gemmatalis evaluated daily, after the application of the nucleopolyhedrovirus (AgNPV) and Bacillus thuringiensis serovar kurstaki (Btk) treatments. observed the desruption of microvilli and a part of the cells was already disorganized and lysed. Bacillus thuringiensis toxins thus appear to bind specifically on the apical membrane of the Lymantria dispar (Lepidoptera, Lymantriidae) larvae epithelial cells (21). According to this study, Raussel et al. (22) were observed the histopathology changes in the midgut of the 3rd instar of Lymantria monacha larvae (Lepidoptera, Lymantriidae) when treated with $B$. thuringiensis toxins, causing vacuolization of the cytoplasm and increase of the cellular volume. Similar effects were observed by Bobrowski et al. (10): disruption of microvilli and vacuolization of

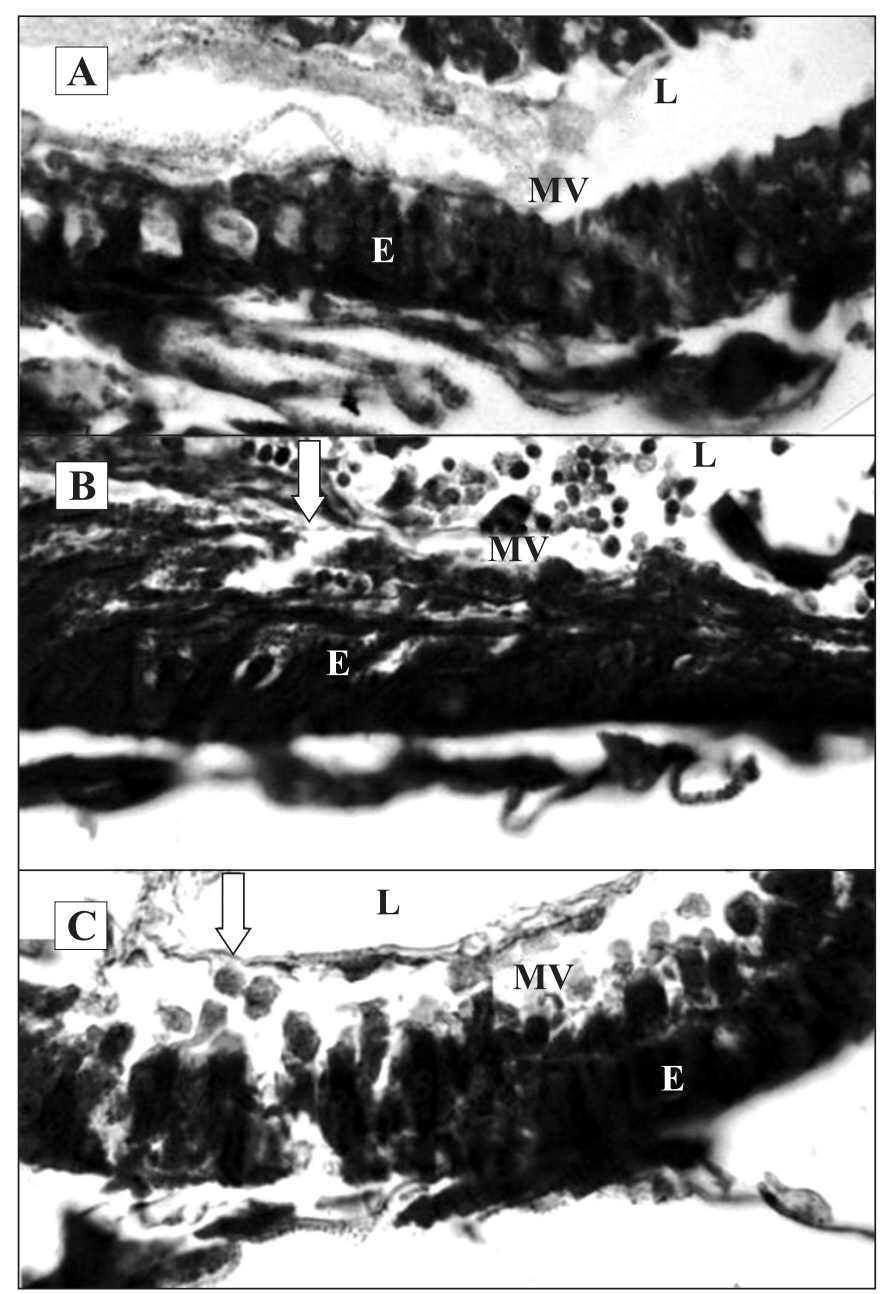

Figure 2. Longitudinal sections of the midgut Anticarsia gemmatalis larvae treated with: (A) Control, not treated; (B) 24 hours after the treatment with Baculovirus anticarsia and Bacillus thuringiensis serovar kurstaki; (C) 24 hours after treatment with Bacillus thuringiensis kurstaki; (E) Epithelium; (L) Lumen; (MV) Microvilli; ( \) Effects caused by the treatments. The slides were amplified 400x. 
cytoplasm began 6 hours after $B$. thuringiensis ingestion by A. gemmatalis larvae. Despite the lower toxicity of Cry1C, synthesized by $B$. thuringiensis serovar kurstaki HD1 strain used in the Dipel biopesticide, which lacks Cry1C, it increased toxicity to Spodoptera exigua (Lepidoptera, Noctuidae). These indicate the half of Cry $1 \mathrm{C}$ was synthesized effectively in this strain, a finding that may increase these strains commercial utility (19). According to Aranda et al. (4), 15 minutes after the application of Cry 1C and Cry 1D in S. frugiperda, it was already possible to observe changes in their cells, however the vacuolization of the cytoplasm, the degradation of the membrane and the destruction of the cells are observed 1 hour after the treatments.

An increase of the cellular volume, vacuolization of the cytoplasm, ejection of a great number of cells in the midgut and disruption on the microvilli were observed in the application of $A g N P V$ (Fig. 2B), after 24 hours of the treatment. Similar results were described by several researches. According to Matos et al. (17) although the virus were not found in the nuclei of columnar cells until late on infection, it is believed that these cells are the primary sites of infection and replication. This fact can be explained by the continuous regeneration of the midgut epithelium. Besides, the infection may be occurring in isolated cells. Pombo et al. (20) observed that 12 hours post infection of $A$. gemmatalis with $A g M N P V$, the cells became round and exhibited a decrease in the number of cytoplasmic projections. The authors described that by 24 hours it was possible to detect a virogenic stroma inside the cell nucleus and after 48 hours, polyhedral inclusion bodies were observed. According to this present study, the Castro et al. (11) evaluated infection of the permissive A. gemmatalis cell line with $A g$ NPV showed pronounced cytopathic effect by 48 hours. These cells were rounded and developed nuclear hypertrophy. Same data was observed by Sciocco-Cap et al. (23), showing in the histological analysis of the 4th instar of Epinotia aporema larva (Lepidoptera, Tortricidae) infected with Baculovirus that were presented the same phases of cellular disruption.

In the Btk/AgNPV association, it was observed that after 6 hours of the application, it had begin disintegrate of the peritrophic membrane and brush border membrane. The cellular lyse was greater and the lumen presented amount of cells after 12 hours of the treatments and this one was intensified after 24 hours. Those observations demonstrated that, in the individual treatments with Btk and $A g \mathrm{NPV}$, until 6 hours after application of the treatments, there were no alterations in the intestinal cells of the A. gemmatalis larva. However, Btk and AgNPV in association, after 6 hours already presented intense vacuolization of the cytoplasm, causing cellular disorganization. After 12 and 24 hours all treatments revealed the alterations (i.e. increase of the nucleus) in the midgut cellular structure of the velvetbean caterpillar.
The in vitro interaction between $A g \mathrm{NPV}$ and $B t k$ showed a difference significant $(\mathrm{P}<0.05)$ when compared whit the treatments isolated. The pathogenicity analysis of AgNPV and Btk in A. gemmatalis larvae suggests that the Dipel and Baculovirus anticarsia products were more efficient when used simultaneously, because the action of $A g \mathrm{VPN}$ was intensified when used in association with Btk, causing changes in the larvae midgut after 6 hours of treatments. Only 12 hours after the treatments, and when the entomopathogens were used isolating, were observed the gut cells alterations.

\section{RESUMO}

\section{Histopatologia de Anticarsia gemmatalis Hübner (Lepidoptera; Noctuidae) tratadas com Virus de Poliedrose Nuclear e Bacillus thuringiensis sorovar kurstaki}

A Anticarsia gemmatalis é responsável pelo uso de inseticidas químicos na cultura da soja, ocasionando um significativo aumento nos custos das lavouras e um grande desequilíbrio no ecossistema. O uso de agentes microbianos, como Bacillus thuringiensis sorovar kurstaki (Btk) e Virus de Poliedrose Nuclear de Anticarsia gemmatalis (VPNAg), é uma alternativa para o controle químico de insetos-praga. Na análise da interação de bactérias e vírus entomopatogênicos, considerase importante o modo de ação in vitro desses agentes de controle microbiano. Assim, o presente trabalho objetiva a análise histopatológica do sistema digestivo das lagartas de $A$. gemmatalis, após a interação dos entomopatógenos Btk e VPNAg, representados nas formulações Dipel e Baculovirus anticarsia, respectivamente. As avaliações foram realizadas com lagartas de $2^{\circ}$ ínstar, onde a mortalidade foi avaliada diariamente, e a histopatologia foi realizada com lagartas coletadas nos períodos de 1, 3, 6, 12 e 24 horas após a aplicação dos tratamentos. Os resultados dos ensaios in vivo, revelam que o tratamento referente à associação VPNAg/Btk (98.68\% de mortalidade) foi mais eficiente que VPNAg (81.28\% de mortalidade) isoladamente, porém o Btk isoladamente causou $100 \%$ de mortalidade. Os tratamentos mostraram diferenças significativas $(\mathrm{P}<0,05)$ entre $A g \mathrm{NPV}$ e Btk, $A g \mathrm{NPV}$ e $A g \mathrm{NPV} / B t k$. As análises de patogenicidade do VPNAg e Btk em lagartas de A. gemmatalis sugerem que os produtos Dipel e Baculovirus anticarsia foram mais eficientes, quando utilizados simultaneamente, pois a ação do VPNA $g$ foi intensificada quando utilizada em associação com $B t k$, provocando alterações no intestino médio das lagartas a partir de 6 horas após os tratamentos. Quando os entomopatógenos foram utilizados isoladamente, as alterações das células intestinais foram observadas apenas 12 horas após a aplicação dos tratamentos.

Palavras-chave: vírus, bactéria, controle biológico, Lepidoptera 


\section{REFERENCES}

1. Abbott, W.S. A method of computing the effectiveness insecticides. J. Econ. Entomol., 18, 265-267, 1925.

2. Abot, A.R.; Moscardi, F.; Fuxa, J.R.; Sosa-Gómez, D.R.; Richter, A.R. Development of resistance by Anticarsia gemmatalis from Brazil and the United States to a Nuclear Polyhedrosis Virus Under Laboratory Selection Pressure. Biol. Control., 7, 126-130, 1996.

3. Alves, S.B. Controle microbiano de insetos. Piracicaba: Ed. FEALQ, 1998, p. 1163.

4. Aranda, E.; Sanchez, J.; Peferoen, M.; Güereca, L.; Bravo, A. Interactions of Bacillus thuringiensis crystal proteins with the midgut epithelial cells of Spodoptera frugiperda (Lepidoptera:Noctuidae). J. Invertebr. Pathol., 68, 203-212, 1996.

5. Azevedo, J.L. Controle microbiano de insetos-praga e seu melhoramento genético. In: Azevedo, L.J.; Melo, I.S. (ed). Controle biológico. Embrapa, São Paulo, 1998, p. 69-96.

6. Barreto, M.R.; Boregas, K.G.B.; Paiva, E.; Valicente, F.H. Banco de da Embrapa milho e sorgo: Bacillus thuringiensis. VII Simpósio de controle biológico, Poços de Caldas, 2001, p. 75.

7. Brandtzaeg, P. Tissue preparation methods for immunocytochemistry. In: Bullock, G.; Petruz, P. (eds) Techniques in immunocytochemistry. Academic Press, London, 1982, p. 49-51.

8. Bobrowski, V.L.; Pasquali, G.; Bodanese-Zanettini, M.H.; Fiuza, L.M. Detection of CRY1 genes in Bacillus thuringiensis isolates from south of Brazil and activity against Anticarsia gemmatalis (Lepidoptera:Noctuidae). Braz. J. Microbiol., 32, 105-109, 2001.

9. Bobrowski, V.L.; Pasquali, G.; Bodanese-Zanettini, M.H.; Fiuza, L.M. Characterization of two Bacillus thuringiensis isolates from south Brazil and their toxicity against Anticarsia gemmatalis (Lepidoptera:Noctuidae). Biol. Control., 25, 129-135, 2002.

10. Bobrowski, V.L.; Scheneumann, R.; Pasquali, G.; Bodanese-Zanettini, M.H.; Fiuza, L.M. Characterization of Bacillus thuringiensis aizawai UNI498 and histopathology analysis of the toxic effect on midgut of the Anticarsia gemmatalis. VIII International Colloquium on Invertebrate Pathology and Microbial Control/XXXV. Annual meeting of the SIP/VI International Conference on Bacillus thuringiensis, Foz do Iguassu, 2002, p.49.

11. Castro, M.E.B.; Souza, M.L.; Araujo, S.; Bilimoria, S.L. Replication of Anticarsia gemmatalis Polyhedrosis Virus in Four Lepidopteron Cell Lines. J. Invertebr. Pathol., 69, 40-45, 1997.

12. Cruz, I. Utilização do Baculovírus no controle da lagarta-do-cartucho do milho, Spodoptera frugiperda. In: Azevedo, L.J.; Melo, I.S. (ed.). Controle Biológico. Embrapa, São Paulo, 2000, p. 201-204.

13. Fuxa, J.R.; Richter, A.R. Repeated reversion of resistance to Nucleopolyhedrovirus by Anticarsia gemmatalis. J. Invertebr. Pathol., 71, 159-164, 1998.
14. Greene, G.L.; Leppla, N.C.; Dickerson, W.A. Velvetbean caterpillar a rearing procedure and artificial medium. J. Econ. Entomol., 69, 487-488, 1976

15. Janmaat, A.F.; Myers,J. Bacillus thuringiensis resistance and associated fitness costs in Trichoplusia ni populations. VIII International colloquium on Invertebrate pathology and microbial control/XXXV Annual meeting of the SIP/VI International Conference on Bacillus thuringiensis, Foz do Iguassu, 2002, p. 67.

16. Levy, S.M.; Gregório, E.A.; Falleiros, A.M.F.; Arrebola, N.R. Estudo Ultraestrutural do tubo digestivo de Anticarsia gemmatalis. VII Simpósio de controle Biológico, Poços de Caldas, 2001, p. 237.

17. Matos, T.G.T.; Giugliano, L.G.; Bergmann, M.R.; Báo, S.N. Structural and ultrastructural studies of Anticarsia gemmatalis midgut cells infected with the baculovirus A. gemmatalis nucleopolyhedrovirus. Int. J. Insect. Morphol. Embryol., 28, 195-201, 1999.

18. Morales, L.; Moscardi, F.; Kastelic, J.G.; Sosa-Gomez, D.R.; Paro, F.R.; Soldorio, I.L. Suscetibilidade de Anticarsia gemmatalis Hübner e Chrysodeixis includens (Walker) (Lepidoptera: Noctuidae), a Bacillus thuringiensis (Berliner). Annais da Sociedade Entomológica do Brasil, 24, 1044-1050, 1995.

19. Park, H.W.; Bideshi, D.K.; Federici, B.A. Molecular genetic manipulation of truncated Cry1C protein synthesis in Bacillus thuringiensis to improve and yield. Appl. Environ. Microbiol., 66, 4449-4455, 2000.

20. Pombo, V.; Velloso, L.M.; Bergmann, M.R.; Báo, S.N. Structural and ultrastructural changes during the infection of UFL-AG-286 cells with the Baculovirus AgMNPV. J. Invertebr. Pathol., 72. 239-245, 1998.

21. Peyronnet, O.; Vachon, V.; Brousseau, R.; Baines, D.; Schwartz, J.L.; Laprade, R. Effect of Bacillus thuringiensis toxins the membrane potential of lepidopteran insect midgut cells. Appl. Environ. Microbiol., 63, 1679-1684, 1997.

22. Rausell, C.; Decker, N.; García-Robles, I.; Esriche, B.; Van Kerkhove, E.; Real, M.D.; Martinez-Ramirez, A.C. Effect of Bacillus thuringiensis toxins on the midgut of the nun moth Lymantria monacha. J. Invertebr. Pathol., 75, 288-291, 2000.

23. Sciocco-Cap, A.; Parola, A.D.; Goldberg, A.V.; Chiringhelli, P.D.; Romanowski, V. Characterization of a Granulovirus Isolated from Epinotia aporema Wals. (Lepidoptera: Tortricidae) Larvae. Appl. Environ. Microbiol., 8, 3702-3706, 2001.

24. Silva, M.T.B. Associação de Baculovírus anticarsia com subdosagem de inseticidas no controle de Anticarsia gemmatalis (Hübner,1818). Ciência Rural, 3, 353-358, 1995.

25. Silva-Werneck, J.O.; Dantas, A.S.; Oliveira, J.A.; Araújo, T.M.R.; Praça, S.F.; Monnerat, R.G. Caracterização de isolados de Bacillus thuringiensis efetivos contra Lepidópteros-praga. VII Simpósio de Controle Biológico, Poços de Caldas, 2001, p. 104. 